\title{
Occurrence of Leishmania chagasi, Trypanosoma cruzi, Babesia canis vogeli, Anaplasma platys, and Ehrlichia canis in canine blood donors
}

\author{
Ocorrência de Leishmania chagasi, Trypanosoma cruzi, Babesia \\ canis vogeli, Anaplasma platys e Ehrlichia canis em cães doadores de \\ sangue
}

\author{
Felipe Augusto Constantino Seabra da Cruz ${ }^{1}$; Amanda Atsumy Funakawa Otsubo ${ }^{2}$; \\ Yolanda Paim Arruda Trevisan²; Thalita Priscila Peres Seabra da Cruz'; \\ Arleana do Bom Parto Ferreira de Almeida ${ }^{3}$; Adriane Jorge Mendonça ${ }^{3}$; \\ Luciano Nakazato ${ }^{3}$; Valéria Régia Franco Sousa ${ }^{3 *}$
}

\begin{abstract}
The transfusion of blood components is common in a veterinary clinic; however, the safety of this therapeutic measure cannot always be guaranteed. Studies show a high risk of haemoparasite transmission during blood transfusion in canines. These parasites include Leishmania chagasi, Anaplasma platys, and Ehrlichia canis, which are endemic to the city of Cuiabá. This study aimed to evaluate the occurrence of L. chagasi, Trypanosoma cruzi, Babesia (canis) vogeli, A. platys, and E. canis in canine blood donor candidates, and identify possible factors associated with the infection of these agents. Sixty-six canines were evaluated using serologic and molecular tests, for the presence of the Leishmania species. While one canine sample showed a positive result for L. chagasi with indirect fluorescent antibody test, with titer of 1:40, and seven canine samples were positive using DPP, all other samples were negative when using PCR and ELISA. All canines were negative for $T$. cruzi when using PCR. The $B$. (c.) vogeli infection was identified in one canine and $A$. platys was identified in six canines. E. canis was identified in 17 canines, with a prevalence of $25.7 \%$. There were no significant factors associated with the infection of the pathogens investigated. Given the observation of infection, even in the absence of clinical symptoms, emphasis must be placed on the need for the use of more sensitive and specific diagnostic methods for the screening of donor canines.
\end{abstract}

Key words: Tick-borne. Visceral leishmaniasis. Trypanosoma. Blood transfusion.

\section{Resumo}

Administração de hemocomponentes é uma prática de rotina na clínica veterinária, entretanto, a segurança nessa medida terapêutica nem sempre é garantida. Estudos mostram risco elevado na transmissão de hemoparasitos pela transfusão sanguínea em cães. Dentre estes, Leishmania chagasi, Anaplasma platys e Ehrlichia canis são endêmicas no município de Cuiabá. Este estudo teve como

\footnotetext{
${ }^{1}$ Discentes de Mestrado, Curso do Programa de Pós Graduação em Ciências Veterinárias, Faculdade de Medicina Veterinária, Universidade Federal de Mato Grosso, UFMT, Boa Esperança, Cuiabá, MT, Brasil. E-mail: felipeseabradacruz@hotmail.com; thaly.prii@hotmail.com

2 Discentes de Graduação, Bolsistas, Programa de Iniciação Cientifica CNPq/UFMT, Faculdade de Medicina Veterinária, UFMT, Boa Esperança, Cuiabá, MT, Brasil. E-mail: atsumyjc@hotmail.com; yolandapaim@hotmail.com

${ }^{3}$ Profs., Faculdade de Medicina Veterinária, UFMT, Boa Esperança, Cuiabá, MT, Brasil. E-mail: arleferreira@gmail.com; adrianejorge.m@gmail.com; lucnak@ufmt.br; valeriaregia27@gmail.com

* Author for correspondence
} 
objetivo avaliar a ocorrência de L. chagasi, Trypanosoma cruzi, Babesia (canis) vogeli, A. platys e E. canis em cães candidatos a doadores de sangue e identificar os possíveis fatores associados à infecção pelos referidos agentes. Dos 66 cães avaliados por exames sorológicos e moleculares para Leishmania sp, um cão reagiu na IFI na titulação 1:40 para L. chagasi., sete no DPP, e todos negativos na PCR e ELISA. Todos os cães foram negativos na PCR para T. cruzi. Foi identificada infecção por Babesia (c.) vogeli em apenas um cão e seis para $A$. platys. E. canis foi diagnosticado em 17 cães, com ocorrência de $25,7 \%$. Não foram observados fatores associados significativamente à infecção pelos patógenos pesquisados. Diante da observação da infecção mesmo na ausência de alterações clínicas, ressalta-se o uso de métodos diagnósticos mais sensíveis e específicos na triagem de cães doadores.

Palavras-chave: Doenças transmitidas por carrapatos. Leishmaniose visceral. Trypanosoma. Transfusão de sangue.

The transfusion of blood components is common in a veterinary clinic. A combination of an in-depth interview with the owner of the canine and the tracking of the potential blood donor are important factors in minimizing the risk of transmission of infectious diseases in veterinary medicine (DAVIDOW, 2013).

The high risk of transmission of agents such as Ehrlichia canis, Babesia canis, Dirofilaria immitis, Borrelia burgdorferi, Brucella canis and Leishmania chagasi during blood transfusions in canines, is a result of the long incubation period, asymptomatic animals and the agent's ability to remain viable in the blood bank (DAVIDOW, 2013). Among these agents, L. chagasi, Anaplasma platys, and Ehrlichia canis are considered endemic in Cuiaba, the study area, with a prevalence of $22 \%$ (ALMEIDA et al., 2012), 9.1\% (WITTER et al., 2013) and 42.5\% (SILVA et al., 2010), respectively. Although they are not considered endemic, infections by Babesia (canis) vogeli and Trypanosoma cruzi have also been reported (SPOLIDORIO et al., 2011; ALMEIDA et al., 2013). Due to the endemicity of these agents in the study area, and the severity of the infections, this study aimed to evaluate the occurrence of pathogens L. chagasi, T. cruzi, B. (canis) vogeli, A. platys, and $E$. canis in candidate canines for blood donation, and identify possible factors associated with the infection of these agents.

We evaluated 66 canines taken to the University Veterinary Hospital for blood donation. The inclusion criteria for donation included: canines weighing more than $25 \mathrm{~kg}$, older than one year, any breed or gender, the absence of pregnancy or lactation, and as a laboratory screening test was used, a haematocrit value greater than $37 \%$ (DAVIDOW, 2013).

After clinical evaluation, local asepsis was confirmed, and approximately $10 \mathrm{ml}$ of blood was collected by cephalic venepuncture. Blood samples with EDTA were used to perform a full blood count, using a Hematology Analyzer Auto Poch100 IV Diff (Roche $\left.{ }^{\circledR}\right)$, and molecular analysis was performed using polymerase chain reaction (PCR). And serum samples were used for the serological evaluation of canine visceral leishmaniasis (CVS) using the immunoassay Dual Plath Platform (DPP), the enzyme-linked immunosorbent assay (ELISA) and indirect fluorescent antibody test (IFAT), performed using commercial kits from Bio-Manguinhos ${ }^{\circledR}$ (FIOCRUZ, Rio de Janeiro), following the manufacturer's guidelines.

The extraction of DNA from the blood samples was performed using the phenol-chloroform method (SAMBROOK et al., 1989). The primers and results used to perform the PCR reactions, and the programs used, are included in Table 1. Amplified products were subjected to $2 \%$ agarose gel electrophoresis for Leishmania sp. and T. Cruzi, and 1.5\% agarose gel electrophoresis for E. canis, A. platys and $B$. (canis) vogeli. They were all stained with Gel Red and visualized in a transilluminator (UV-300nm) Chemi-doc (Bio-Rad $\left.{ }^{\mathrm{TM}}\right)$. 
Statistical analysis for the identification of the factors (sex, breed, street access and tick infestation) associated with the pathogens was performed using the Chi-Squared test or Fisher's Exact, with the Epi Info 3.3.2 software (CDC, Atlanta, USA). A significance level of $5 \%$ was used.

The 66 potential donors which were assessed were from the municipalities of Baixada Cuiabana, mainly Cuiabá. Of these, 32 were female and 34 were male, with a mean age of 5.2 years (median 4 years). Twenty-seven of the canines were of a mixed breed, whilst nine breeds were identified as follows, in descending order: American Pit Bull Terrier (17), Rottweiler (5), Boxer (5), Labrador Retriever (4), German Shepherd (4), Dalmatian (1), Akita (1), Siberian Husky (1), and Fila Brasileiro (1).

Table 1. Primers used in PCR infection research of Leishmania sp., Ehrlichia canis, Babesia (canis) vogeli, Trypanosoma cruzi, and Anaplasma platys in canine blood donor candidates.

\begin{tabular}{llc}
\hline \multicolumn{1}{c}{ Pathogens } & \multicolumn{1}{c}{ Primer (5' e 3') } & \multicolumn{1}{c}{ References } \\
\hline \multirow{2}{*}{ Leishmania sp. } & 150: GGG(G/T)AGGGGCGTTCT(C/G)CGAA & Lachaud et al. (2002) \\
& 152: (C/G)(C/G)(C/G)(A/T)CTAT(A/T)TTACACCAACCCC & \\
& ECC: AGAACGAACGCTGGCGGCAAGCC & \\
Ehrlichia canis & ECB: CGTATTACCGCGGCTGCTGGGC & Murphy et al. (1998) \\
& ECAN: CAATTATTTATAGCCTCTGGCTATAG & \\
& HE3: TATAGGTACCGTCATTATCTTCCCTAT & \\
Babesia (canis) vogeli & BAB1: GTGAACCTTATCACTTAAAGG & Duarte et al. (2008) \\
& BAB4: CAACTCCTCCACGCAATCG & \\
Trypanosoma cruzi & D71: AAGGTGCGTCGACAGTGTGG & Souto and Zingales (1993) \\
& D72: TTTTCAGAATGGCCGAACAGT & \\
Anaplasma platys & Platys-F: AAGTCGAACGGATTTTTTC & Inokuma et al. (2002) \\
\hline
\end{tabular}

An increased healthcare of the canine donors provides safer blood transfusions (DAVIDOW, 2013), a fact that should be promoted in this population as the management of vaccinations and anthelmintic treatments was performed in only 55 (83.3\%) and 39 (59.1\%) canines, respectively.

There was no evidence of DNA amplification of $T$. cruzi in the canines evaluated in this study. However, the infection by this parasite in canines from Cuiaba has been previously reported (ALMEIDA et al., 2013), highlighting the importance of further research of this pathogen.

There was no DNA amplification of the Leishmania sp. in any canine sample, and the serological analysis showed that samples from seven canines were positive using the screening test. However, only one sample was positive with IFAT, and no Leishmania sp. was detected by antibodies using the ELISA technique. The ELISA is currently recommended by the Ministry of Health as a confirmation test for CVL (BRASIL, 2011). Technical Note $n^{\circ}$ 01/2011 - CGDT/CGLAB/ DEVIT/SVS/MS) in endemic areas, which the region in this study is classified as (ALMEIDA et al., 2012). The prevalence of $10.6 \%$ seropositive canines using one of the techniques for CVL identification is similar to that presented by França et al. (2013), who detected the presence of antiLeishmania antibodies in $15.6 \%$ of samples from human donors in an endemic area of Mato Grosso do Sul. 
According to Scarlata et al. (2008), a positive result using serological tests does not necessarily indicate an active infection, and may be a result of a previous exposure to the parasite, especially in endemic regions. In this study, seropositive canine samples did not have any DNA detection of the infection when using PCR, which is considered a more sensitive and specific test. This could possibly have been identified in the bloodstream if it were an active infection (DAVIDOW, 2013).

Infection with $B$. (canis) vogeli was identified in only one canine without haematological changes and tick infestation. This result reinforces the possibility that the presence of the infection is associated with a blood transfusion, as reported by Stegeman et al. (2003).
E. canis was diagnosed in 17 canines, resulting in a prevalence of $25.7 \%$. The E. canis infection in canine candidate donors was not associated with gender, breed, street access, and / or tick infestation. Santos et al. (2013) also found no predisposition to infection according to gender and breed in a population of canines in Mato Grosso, Pantanal. The transmission of E. canis is directly related to the distribution of the vector (Table 2); however, there was no significant association between the presence of the vector or with access to the street, as described by Silva et al. (2010). This may be due to the low canine tick infestation at certain times of year, consistent with published research. However, the low number of included canines may have reduced the power and ability to identify an association between the factors and the infections.

Table 2. Variables evaluated for association testing with infection by Ehrlichia canis and Anaplasma platys.

\begin{tabular}{|c|c|c|c|c|c|}
\hline \multirow{2}{*}{$\frac{\text { Variables and Categories }}{\text { Sex }}$} & \multirow[t]{2}{*}{ Dogs } & \multicolumn{2}{|c|}{ Ehrlichia canis } & \multicolumn{2}{|c|}{ Anaplasma platys } \\
\hline & & Positive (\%) & $\mathrm{P}$ & Positive (\%) & $\mathrm{P}$ \\
\hline Male & 34 & $8(23,5)$ & & $3(8,8)$ & \\
\hline Female & 32 & $9(28,1)$ & 0,88 & $3(9,3)$ & 0,63 \\
\hline \multicolumn{6}{|l|}{ Breed } \\
\hline Pure & 39 & $9(23,1)$ & & $2(5,1)$ & \\
\hline Mixed & 27 & $8(29,6)$ & 0,75 & $4(14,8)$ & 0,21 \\
\hline \multicolumn{6}{|l|}{ Access to the street } \\
\hline Yes & 34 & $11(45,8)$ & & $4(16,6)$ & \\
\hline No & 32 & $6(18,7)$ & 0,32 & $2(6,2)$ & 0,24 \\
\hline \multicolumn{6}{|l|}{ Ticks } \\
\hline Yes & 31 & $7(22,6)$ & & $2(6,4)$ & \\
\hline No & 35 & $10(28,6)$ & 0,78 & $4(11,4)$ & 0,42 \\
\hline
\end{tabular}

Infection with $A$. platys was detected in six (9.1\%) co-infected canines with $E$. canis. The coinfection of these agents is common, as both use the same vector for infection of the host (SANTOS et al., 2013). The occurrence of these pathogens is similar to that obtained by Witter et al. (2013), who studied symptomatic canines within the same area. It is important to note that the canines in this study had no apparent clinical symptoms of the infection.
In conclusion, this study identified the infection of $E$. canis, A. platys, and B. (c) vogeli in candidate blood donor canines, in the absence of clinical symptoms, emphasizing the importance of using more sensitive diagnostic methods, such as PCR, for the screening of donor canines. There were no factors significantly associated with the infection by pathogens studied. 


\section{References}

ALMEIDA, A. B. P. F.; PAULA, D. A. J.; OTTON, M. L. P.; JAUNE, F. W.; CRUZ, R. A. S.; MADEIRA, M. F.; NAKAZATO, L.; MENDONÇA, A. J.; PESCADOR, C. A.; SOUSA, V. R. F. Natural infection by Trypanosoma cruzi in one dog in central western brazil: a case report. Revista do Instituto de Medicina Tropical de São Paulo, São Paulo, v. 55, n. 4, p. 287-289, 2013.

ALMEIDA, A. B. P. F.; SOUSA, V. R. F.; CRUZ, F. A. C. S.; DAHROUG, M. A. A.; FIGUEIREDO, F. B.; MADEIRA, M. F. Canine visceral leishmaniasis: seroprevalence and risk factors in Cuiabá, Mato Grosso, Brazil. Revista Brasileira de Parasitologia Veterinária, Jaboticabal, v. 21, n. 4, p. 359-365, 2012.

DAVIDOW, B. Transfusion medicine in small animals. Veterinary Clinics of North America: Small Animal Practice, Philadelphia, v. 43, n. 4, p. 735-756, 2013.

DUARTE, S. C.; LINHARES, G. F. C.; ROMANOWSKY, T. N.; SILVEIRA NETO, O. J.; BORGES, L. M. F. Assessment of primers designed for the subspeciesspecific discrimination among Babesia canis canis, Babesia canis vogeli and Babesia canis rossi by PCR assay. Veterinary Parasitology, Amsterdam, v. 152, n. 1-2, p. 16-20, 2008.

FRANÇA, A. O. F.; CASTRO, V. L.; LIMA JUNIOR, M. S. C.; PONTES, E. R. J. C.; DORVAL, M. E. C. D. AntiLeishmania antibodies in blood donors from the Midwest region of Brazil. Transfusion and Apheresis Science, Oxford, v. 49, n. 3, p. 627-630, 2013.

INOKUMA, H.; FUJII, K.; MATSUMOTO, K.; OKUDA, M.; NAKAGOME, K.; KOSUGI, R.; HIRAKAWA, M.; ONISHI, T. Demonstration of Anaplasma (Ehrlichia) platys inclusions in peripheral blood platelets of a dog in Japan. Veterinary Parasitology, Amsterdam, v. 110, n. 1-2, p. 145-152, 2002.

LACHAUD, L.; MARCHERGUI-HAMMAMI, S.; CHABBERT, E.; DEREURE, J.; DEDET, J.P.; BASTIEN, P. Comparison of Six PCR Methods Using peripheral blood for detection of canine visceral leishmaniasis. Journal of Clinical Microbiology, Washington, v. 40, n. 1, p. 210-215, 2002.

BRASIL. Ministério da Saúde, Secretaria de Vigilância em Saúde, Departamento de Vigilância das Doenças Transmissíveis. Nota Técnica Conjunta $n^{\circ}$ 1, de 2011. Esclarecimentos sobre substituição do protocolo diagnóstico da leishmaniose visceral canina (LVC). Brasília: Coordenação Geral de Doenças Transmissíveis/ Coordenação Geral de Laboratórios de Saúde Pública. 2011.
MURPHY, G. L.; EWING, S. A.; WHITWORTH, L. C.; FOX, J. C.; KOCAN, A. A. Molecular and serologic survey of Ehrlichia canis, Ehrlichia chaffeensis, and E. ewingii in dogs and ticks from Oklahoma. Veterinary Parasitology, Amsterdan, v. 79, n. 4, p. 325-339, 1998.

SAMBROOK, J.; FRITSCH, E. F.; MANIATIS, T. Molecular cloning: a laboratory manual. $2^{\text {th }}$ ed. New York: Cold spring Harbor Laboratory Press, Cold Spring Harbor, 1989. v. 1, 1626 p.

SANTOS, L. G. F.; MELO, A. L. T.; MORAES-FILHO, J.; WITTER, R.; LABRUNA, M. B.; AGUIAR, D. M. Molecular detection of Ehrlichia canis in dogs from the Pantanal of Mato Grosso State, Brazil. Revista Brasileira de Parasitologia Veterinária, Jaboticabal, v. 22, n. 1, p. 114-118, 2013.

SCARLATA, F.; VITALE, F.; SAPORITO, L.; REALE, S.; VECCHI, V. L.; GIORDANO, S.; INFURNARI, L.; OCCHIPINTI, F.; TITONE, L. Asymptomatic Leishmania infantum/chagasi infection in blood donos of western Sicily. Transactions of the Royal Society of Tropical Medicine and Hygiene, Oxford, v. 102, n. 4, p. 394-396, 2008.

SILVA, J. N.; ALMEIDA, A. B. P. F.; BOA SORTE, E. C.; FREITAS, A. G.; SANTOS, L. G. F.; AGUIAR, D. M. Soroprevalência de anticorpos anti-Ehrlichia canis em cães de Cuiabá, Mato Grosso. Revista Brasileira de Parasitologia Veterinária, Jaboticabal, v. 19, n. 2, p. 108111, 2010.

SOUTO, R. P.; ZINGALES, B. Sensitive detection and strain classification of Trypanosoma cruzi by amplification of a ribosomal RNA sequence. Molecular and Biochemical Parasitology, Amsterdam, v. 62, n. 1, p. 45-52, 1993.

SPOLIDORIO, M. G.; TORRES, M. M.; CAMPOS, W. N. S.; MELO, A. L. T.; IGARASHI, M.; AMUDE, A. M. Molecular detection of Hepatozoon canis and Babesia canis vogeli in domestic dogs from Cuiabá, Brazil. Revista Brasileira de Parasitologia Veterinária, Jaboticabal, v. 20, n. 3, p. 253-255, 2011.

STEGEMAN, J. R.; BIRKENHEUER, A. J.; KRUGER, J. M.; BREITSCHWERDT, E. B. Transfusion-associated Babesia gibsoni infection in a dog. Journal of American Veterinary Medical Association, Chicago, v. 222, n. 7, p. 959-963, 2003.

WITTER, R.; VECCHI, S. N.; PACHECO, T. A.; MELO, A. L. T.; BORSA, A.; SINKOC, A. L.; MENDONÇA, A. J.; AGUIAR, D. M. Prevalência da erliquiose monocítica canina e anaplasmose trombocítica em cães suspeitos de hemoparasitose em Cuiabá, Mato Grosso. Semina: Ciências Agrárias, Londrina, v. 34, n. 6, p. 3811-3822, 2013. 
